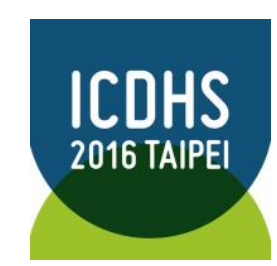

\title{
Towards a new paradigm:
}

Applying industrial design processes to the craft bamboo industry

Hung-Wei Lee / Gianni Renda / Carolyn Barnes / Swinburne University of Technology / Melbourne / Australia

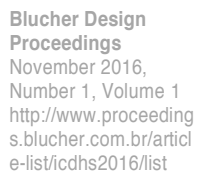

\begin{abstract}
The craft bamboo industry in Taiwan has been in steady decline since 1985. In recent years, the government has attempted to stimulate this industry by promoting this craft as a distinct form of national culture and identity; however there is a disconnect between the desires of national policy objectives and the effort required to raise the state of play in Taiwan's bamboo crafts and product sectors to compete on a global scale and attain a desirable level of demand. The research aims to demonstrate that an industrial design-led approach is required within the craft bamboo industry to revitalise the sector.
\end{abstract}

\section{Keywords}

Craft, cultural Industry, cross-functional cooperation, bamboo, industrial design

\section{Introduction}

The development of bamboo crafts in Taiwan can be traced to the practices of Taiwan's indigenous peoples and later to Han Chinese immigrants; both groups using local materials to address daily needs (Cheng, 2010). Traditional bamboo craft workers were both designers and producers, producing individual designs using a range of techniques and offering a distinct product to modern process-driven designs. Production met basic standards of practicality and design, with the majority of artefacts being easy to produce and low-cost. Since the early twentieth century, there has been some tension between preserving traditional craft techniques and developing new, industrial-scalable products from bamboo.

\section{Craft based approaches}

Craft is both a title for a field of cultural practice and a term that relates to how skilfully one creates an artefact in fields ranging across art, craft and design. In early agricultural societies—such as Taiwan — craft was the practice used to manually produce items ranging from tools to utensils and garments, including those that were used for ceremonial purposes, being elaborately produced to mark their ritual use (Huang, 2001). In discussing the value of craft, Karppinen (2008) cites the German philosopher Hannah Arendt's (1958/2000) identification of three fundamental human activities; labour, work and action. Arendt links work with skill and technique, craft products and cultural heritage, the expression of skilfulness and knowledge in the activity of hand production making human life meaningful. Kikuchi (2015) and Huang (2001) contend that craft is a broadly defined set of human activities inherently related to human nature and vital for human fulfilment and enlightenment.

\section{Bamboo industries and related design education}

From the early Qing dynasty (1644-1911), Taiwan exported indigenously designed and made products to Mainland China (The Nantou County Department of Cultural Affairs, 2015). These early products can be divided into three categories: carpentry, carving and weaving. They included large-scale products such as bamboo furniture and bamboo cages for keeping livestock. From 1936, Japanese craftsmen introduced techniques such as weaving and fretwork to Taiwan, initiating the production of sophisticated and technically advanced goods such as cases and baskets (Cheng and Won, 2010). However, since the early twentieth century there has also been a tension between preserving traditional craft techniques and developing new industrial products from bamboo; for example using high- 
temperature pressure machines to make laminated bamboo flooring. The period from 1975 to 1985 was the golden age for bamboo products in Taiwan. The local government in Zhushan Town, Nantou County, encouraged the growth by establishing a specialized bamboo craft education program at National Zhushan High School. This school was focused on traditional techniques, rather than the design and manufacturing techniques for contemporary consumer products. Many of the bamboo craft workers trained at National Zhushan High School continue to produce work in a craft-based, studio fashion; this being increasingly out of step with changing market conditions and expectations.

Unfortunately in 2010, these bamboo craft classes ended (National Zhushan Senior High

School, 2016). In other schools, there had been no design tutoring related to bamboo until 2008; the passing of the 'Cultural and Creative Industry Development Law' saw the government seeking to raise the level of community cultural engagement and to promote 'Brand Taiwan' internationally. Furthermore, some universities began to offer design classes related to bamboo craft. There are now five universities which offer bamboo craft training within design education in 2015 (Ministry of Education, 2016).

\section{Policies and preserving the master's tradition in the face of decline}

Two published case studies (Lin, 2012, Gao, 2012) report Taiwanese government initiatives for the bamboo crafts sector. The 2007 'The new interdisciplinary process for authoring application', jointly managed by the Taiwan Design Centre and Taiwan Craft Research Development Centre invited designers and crafts people from fields including bamboo, lacquer and glass to collaborate. Lin (2012) argues that the rebranding of Taiwanese crafts in 2008 under the auspices of the project under the brand name 'Yii' for the international market, sought to project a contemporary outlook for Taiwanese craft, while the focus on current design trends and production factors sought to drive successful development of new products. The second initiative, 'Slow living mixed media product development' had bamboo as a theme and linked craftspeople with design consultancies and teams for the same end.

The finest bamboo craftworks require the performance of high-level techniques and abilities, so in 2009, Taiwan's government instituted a campaign to promote the living crafts movement across the country, where craftsmen may be elected to the 'Taiwan Craft Family' honours roll. Once elected, the value of their past and future work increases significantly. Because of the lack of formal training in bamboo crafts in Taiwan, few craft workers have the skills to achieve such a standard. Faced with craft industries in decline, in 2013 Taiwan's Council of Labour Affairs launched a plan, the title of which can be loosely translated as 'Using Famous Masters to Teach Good Apprentices' (Taiwan Workforce Development Agency Ministry of Labor, 2015). The program provides training in professional skills for various heritage crafts through an apprenticeship system. The program offers training in 25 traditional skills categories, including bamboo products. Graduates of the program receive an award from the Ministry of Labour the Workforce Development Agency Skills Certification Centre. After training, effort is made to help the trainee make a smooth integration into employment (Taiwan Workforce Development Agency Ministry of Labor, 2015).

\section{The value to local industry}

For Wang et al. (2011), bamboo crafts perpetuate Taiwan's cultural heritage, with bamboo weavers and crafts people reporting their work to secure knowledge of traditional bamboo weaving techniques and to digitize Taiwan's bamboo arts and crafts. They provide a strong argument for the value of bamboo as a craft material that is readily accessible for the creation of a range of contemporary products. Kettley (2012) discusses contemporary business trends and the values of 'craftivism' and the Slow Movement for emerging crafts peoples and makers. Globalisation has been contested by a number of movements. The Slow Movement, originating in Italy, has promoted the value of local produce and skills as against an industrialised consumerism that have erased meaningful differences between time and place (Petrini, 2005). The reaction against consumerism has recently taken a more political expression through emergence of ethical consumerism (Auger et al., 2007), the Fair Trade movement seeking to connect consumers with the lives of producers, including in the area of craft products (Lyon, 2006).

\section{Can Taiwan learn from Europe?}

Across Europe, there was a push for the industrialization of traditional craft production, design being understood as the new industrial art, not an extension of craft. An outgrowth of the Deutsche Werkbund, the Bauhaus (1919-1933) built a design curriculum based on a synthesis of art, science, and technology to educate future designers by making 
a primary distinction between Formlehre and Werklehre; the study of form versus crafting (Delle Monache and Rocchesso, 2014). The curriculum of the Basic Course, the first year of study at the Bauhaus, focused on research rather than creation, comprising exercises and problems to be solved within the framework of specific constraints such as economy of time or reduction of means and parameters (Stefano Delle Monache, 2014).

Bauhaus design philosophy and design processes were not systematically taught or used in

Taiwan until around 1970 when Taiwan's economy began to truly grow and modernize (Huang, 2001). Of particular interest here is the principle of 'pragmatic academics' found in the Taiwanese curriculum for handicrafts. Lessons covering basic drafting, woodwork, weaving and ceramics - as well as modeling - emphasised both the essence of Bauhaus notions of handiwork manipulation and the industrial application of design as in Bauhaus design education (Yao et al., 2013).

\section{Engaging with industrial design processes}

As previously established, Taiwan's bamboo manufacturing industry uses traditional management practices to run production processes, lacking expertise in design management. Shah (2000) argues, however, that 'There is empirical evidence that innovations can be developed by those holding any of a number of functional relationships to them, such as manufacturers, users, or materials suppliers. Roberto (2008) contends that design-driven innovation is urged along by a company's vision about possible future product languages and meanings. The process these companies

follow suggest the major modes of innovation: 1) design-driven innovation, where innovation starts from a company's understanding of the nuanced, tacit undercurrents within socio-cultural groups and can harness these to create new languages and meanings; 2) market-pull innovation, where innovation begins with the analysis of consumer needs and preferences and then searches for the technical means and aesthetic and symbolic languages to fulfil them; 3) technology-push innovation that leverages the dynamics of technological research. Both Shah (2000) and Roberto (2008) recommend design-driven innovation as the way to push a company's vision the furthest, but all three modes of innovation would aid NPD for Taiwan's bamboo products manufacturers. Taiwan already engages heavily with industrial design; companies such as Giant Bicycles, Acer and HTC are known for their high quality products with strong aesthetic sensibilities; a future may be envisioned where craft manufacturers appropriate the design techniques of the aforementioned firms to produce world-leading products with a strong customer focus.

\section{Conclusion}

An identification of industrial design approaches and driven innovation might stem the decline of Taiwan's bamboo crafts and manufactured products industries by developing products that consumers actually want. In recent decades, the viability of Taiwan's bamboo crafts and manufactured products sectors has suffered from competition large-scale industrial copying and from cheap plastic versions of goods formerly made in bamboo.

The above literature suggests a range of factors as contributing barriers here including poor grasp of the nature and differences between art, craft and design; a lack of suitably trained workers; a lack of focus on bamboo as a material in design innovation, a lack of industrial design-led approach knowledge at companies, individual companies preferring to struggle on alone, and strong external competition from global, low-cost manufacturers. The one bright spot is the Taiwanese government's interest in and support for heritage cultural industries despite the need for more effectively targeted initiatives. The usage of industrial design processes, appropriated from the high tech industry may help develop and engage further with the craftsmen and elevate the products to an international audience. The processes of methods are design-driven innovation, market-pull innovation and technology-push innovation. Three modes of innovation would aid NPD for Taiwan's bamboo products manufacturers.

\section{References}

Auger, P., Devinney, T. and Louviere, J. (2007) 'Measuring the Importance of Ethical Consumerism: A Multi Country Empirical Investigation'. Controversies in international corporate responsibility: In Madsen, $P$. and Hooker, J. (ed.).

Cheng, W.-T. (2010) 'A Study on the Attractiveness Factors for Local Craft Industry- A Case for Bamboo Industry in Zhu-Shan, Nan-Tou County [地方工藝產業魅力因子研究一以南投縣竹山鎮竹藝產業為例]'. Master, Tokai University, Taiwan.

Delle Monache, S. and Rocchesso, D. (2014) 'Bauhaus Legacy in Research through Design: The Case of 
Basic Sonic Interaction Design'. International Journal of Design, vol.8, pp.139-154.

Gao, Y.-F. (2012) 'The Development, Transformation and Cultural Creativity of Bamboo Craft Industries in Jhushan Town [竹山竹工藝產業的發展轉型與文化創意]'. PhD, Yunlin University of Science and Technology, Taiwan.

Huang, X.-Z. (2001) 'Modern design and aesthetic significance of Taiwan Craft [ 臺灣工藝現代化在設計及審 美上的意義]'. Taiwan Craft, vol. 8, pp. 4-10.

Karppinen, S. (2008) 'Craft-Art as a Basis for Human Activity'. International Journal of Art \& Design Education, vol. 27, pp. 83-90.

Kettley, S. (2012) 'The foundations of craft: A suggested protocol for introducing craft to other disciplines'. Craft Research, vol. 3, pp. 33-51.

Kikuchi, Y. (2015) 'The craft debate at the crossroads of global visual culture: re-centring craft in postmodern and postcolonial histories'. World Art, pp. 1-29.

Lin, H.-M. (2012) 'The Study on Production Model of Modern Bamboo Design [以竹材探討現代工藝設計之 產品化模式]'. Master, Southern Taiwan University of Science and Technology.

Lyon, S. (2006) 'Evaluating fair trade consumption: Politics, defetishization and producer participation'. International Journal of Consumer Studies, vol. 30, pp. 452 - 464.

Ministry of Education. (2016). [Online]. http://depart.moe.edu.tw/ED2300/Default.aspx.

National Zhushan Senior High School. (2016). 'History Memorabilia [沿革大事記]' [Online].

http://www.cshs.ntct.edu.tw/.

Petrini, C. (2005) Slow food revolution, New York, Rizzoli Inc.

Roberto, V. (2008) 'Design, Meanings, and Radical Innovation- A Metamodel and aResearch Agenda'. PROD INNOV MANAG, vol. 25, pp. 436-456.

Shah, S. (2000) 'Sources and Patterns of Innovation in a Consumer Products Field- Innovations in Sporting Equipment'. Massachusetts Institute of Technology.

Stefano Delle Monache, D. R. (2014) 'Bauhaus Legacy in Research through Design: The Case of Basic Sonic Interaction Design'. International Journal of Design, vol. 8.

Taiwan Workforce Development Agency Ministry of Labor. (2015) 'Using famous masters to teach good apprentices [名師出高徒]' [Online]. Available:

http://www2.evta.gov.tw/safe/docs/safe95/userplane/video_display.asp?menu_id=8\&submenu_id=440\&ap_ id $=1848 \&$ cat $=2013$

Wang, K.-A., Liao, Y.-C., Chu, W.-W., John, Y.-W. C., Chen, Y.-F. and P-C., C. (2011) 'Digitization and Value-Add Application of Bamboo Weaving Artifacts' Lecture Notes in Computer Science, vol. 7008, pp. 1625.

Yao, T.-H., Sun, C.-Y. \& Lin, P.-C. (2013) 'Modern Design in Taiwan: The Japanese Period, 1895-1945'. Design Issues, vol. 29, pp. 38-51.

\section{Biographical note}

Hung-Wei Lee is a PhD candidate at Swinburne University of Technology in Australia. His family has been part of Taiwan's bamboo forestry industry for four generations. Hung-Wei has implemented bamboo industry projects in Dominican Republic for Taiwan's International Corporation and Development Fund. His research investigates design-led innovation and industry renewal.

Dr Gianni Renda (PhD Swin 2013) is Course Coordinator of the Bachelor of Industrial Design program at Swinburne University of Technology. Gianni is also Deputy Director of the Swinburne BioReactor, an ARC Training Centre developing new, empowering products and technologies for the health sector, including for disability and ageing.

Associate Professor Carolyn Barnes (PhD Melb 2004) is Academic Director of Research Training in the Swinburne School of Design where she teaches research methods for academic and practice applications. Her research investigates how to harness the knowledge and power of individuals and groups to address their primary needs and interests. 